\title{
Are Students of East European Universities Subjects of Educational Services?
}

\author{
Valery Okulich-Kazarin \\ School of Entrepreneurship, Wroclaw University of Environmental and Life Sciences, Wroclaw, Poland
}

Received January 29, 2020; Revised February 21, 2020; Accepted April 7, 2020

Copyright $(2020$ by author, all rights reserved. Author agrees that this article remains permanently open access under the terms of the Creative Commons Attribution License 4.0 International License

\begin{abstract}
The goal of the study was verification of the hypothesis: students of East European universities are subjects of educational services. The study was carried out since December 2018 till December 2019. The following research methods were used in the work: empirical methods (the study of normative legal acts and scientific-methodological literature; content analysis of scientific sources and standards for higher professional education; monitoring of publications); methods of theoretical analysis (comparative and retrospective one; specification and generalization; classification; induction and deduction); mathematical and graphical methods for data analysis of research, verification of statistical hypotheses. The legal relations between the subjects of educational services in some East European countries have been studied. The results have a very important scientific and practical significance: 1 . It is statistically proven that students of East European universities are not subjects of educational services. The result is highly statistically significant (0.01). 2. There were given recommendations for Governments of East European countries. 3. There were given recommendations for the authorities of East European universities.
\end{abstract}

Keywords Educational Services, Subjects of Educational Services, Paid Educational Services, Legal Relations

\section{Introduction}

The study is a small part of a large research of educational services in Eastern European Universities. The study was carried out at the East European Scientific Group since December 2018 till December 2019. The common research was initiated in December 2016.

You know the topic of the educational services was in demand about 40-50 years ago. At the beginning of the 21st century, researchers continued to study issues of student service, motivation, activity, and satisfaction [1-6].

In the last three years, papers related to the study of educational services in Eastern Europe have been published [7-13]. However, these papers studied local problems of providing educational services in East European universities.

Eleven variants of the definition of "educational services" were analyzed from the standpoint of economic theory in the article [14]. Here the definitions were divided into two groups:

- the first group in which the performer "provides" educational services, and the consumer of educational services acts as a passive object of its receipt (there are eight definitions),

- the second group in which the consumer acts as an active subject of educational services (there are three definitions).

In this study, the author shows the overall picture regarding subjects of educational services in East European countries. This topic is very important because the definition of "subject" of educational services applies not only to legal Sciences, but also to psychological and pedagogical Sciences [15].

\section{Methods}

\subsection{General Information}

The study was carried out at the East European Scientific Group since December 2018 till December 2019. The practical part of the study was focused regionally, in East Europe. From a theoretical point of view, the author relied on studies carried out in different countries before that.

The object of the study is educational services in 
East-European universities.

The subject of the study is legal relations between subjects of educational services in East-European universities.

The goal of the study is verification of the hypothesis: students of East European universities are subjects of educational services.

The Research hypothesis: students of East European universities are subject of educational services.

\subsection{Research Techniques}

The following research methods were used in the study:

- $\quad$ empirical methods (the study of normative legal acts and scientific-methodological literature; content analysis of scientific sources and standards for higher professional education; monitoring of publications);

- methods of theoretical analysis (comparative and retrospective one; specification and generalization; classification; induction and deduction);

- mathematical and graphical methods for data analysis of research, verification of statistical hypotheses [16].

The study was performed in three stages:

- literature review,

- processing and grouping of results for same East European countries,

- verification of statistical hypotheses.

At the first stage, the description of the state of research in this field was made. The literature review was performed in two steps. When the author was selecting countries for legal analysis, he tried to ensure maximum diversity. In order to achieve maximum diversity, the selection of specific countries was made on the following three grounds:

1. Entry into the European Union:

- the countries of the European Union

- non-European Union countries

2. Economic indicators:

- countries with a Per capita GDP of more than $\$ 20,000$

- $\quad$ countries with a Per capita GDP of \$ 10,000 to $\$ 20,000$

- countries with a Per capita GDP of less than $\$ 10,000$

3. Population:

- large countries (with a population of more than 40 million people),

- medium-sized countries (with a population of 20-40 million people),

- $\quad$ small countries (with a population of less than 20 million people).

So, eight countries were selected for further analysis:
Azerbaijan, Belarus, Croatia, Czech Republic, Poland, Russia, Serbia and Ukraine.

After the literature review the goal of the study was formulated.

At the second stage, it was the processing and grouping of results such as normative legal acts and scientific-methodological literature and standards for higher education.

At the third stage, the Research Hypothesis was formulated and verified: students of East European universities are subjects of educational services.

At last, after discussion of the received results, the author has made the conclusion.

\section{Literature Review}

\subsection{Legal Regulatory of Relations between the Subjects of Educational Services in Europe}

The essence of the relationship between a citizen and the state changes under market conditions. Education becomes the sphere of educational services [17], and the citizen-taxpayer receives the rights of consumers and requires improving the quality of services provided, taking into account the needs of consumers.

The formation and development of the educational services market is a complex process. Awareness of education as a service and its entry into the market implies the inclusion of market levers, including legal relations between the subjects of educational services.

On September 15, 2015, the ISO 9001:2015 [18] standard was officially published. This standard is one of the three fundamental standards developed by ISO / TS 176 Technical Committee of the International Organization of Standardization. Its purpose is to meet the needs of the customer/buyer of goods or services. The terms "service" only applies to services intended for, or required by, a customer.

The ISO 9001:2015 standard is based on the principles of quality management. The first principle of the standard is a customer focus [18, Art. 1.2]. This International Standard specifies requirements for a quality management system when an organization:

a) needs to demonstrate its ability to consistently provide products and services that meet customer and applicable statutory and regulatory requirements, and

b) aims to enhance customer satisfaction ... and the assurance of conformity to customer and applicable statutory requirements.

The standards of the ISO 9000 series [18], adopted by more than 190 countries of the world as national, are applicable to any enterprises, regardless of their size, ownership or sphere of activity. Thus, there is an international document that regulates the relationship between the provider and the consumer of educational 
services, including in Eastern Europe. So, the provision and receipt of educational services in universities should be carried out on the basis of current legislation.

\subsection{Legal Relations between the Subjects of Educational Services in the Selected East European Countries}

The conditions for the provision and receipt of higher education educational services in some East European countries will be described below. The author only will focus on one aspect. This is: do the Laws of the country consider students as subjects of educational services?

\section{Azerbaijan}

The main document regulating educational activities is the Law "On Education" [19]. In Art. 1, the definition of "educational product" is shown: innovations in the field of education, original educational and subject programs, systems of teaching methods, educational modules, educational projects [19, Art. 1]. According to this definition, the legislation of Azerbaijan is focused on "educational franchising".

The main goal of education [19, Art. 4] shows the passive role of the student. Therefore, student cannot be considered a subject of educational activity.

\section{Belarus}

The right of citizens of the Republic of Belarus to education is ensured by the "creation of conditions for education, taking into account national traditions, as well as individual needs, abilities and needs of students" [20, Art. 3]. From this legal norm it follows that the student is the subject of educational activities and may affect the quality of the educational services received. Therefore, the student can be considered the subject of educational services.

\section{Croatia}

In Croatia, there are several Laws governing educational activities [21, 22]. We can see that the student is allowed to think independently and have a personal opinion. He can even evaluate the work of teaching staff. However, he cannot claim to meet his educational needs. In other words, the student is not the subject of educational services.

And only Art. 2 of the Law "On Adult Education" [23] speaks about adult education on the principles: ..., "freedom and independence in choosing the ways, content, forms, resources and method", ... In this case, there is an opportunity to be a full subject of educational services.

\section{Czech Republic}

Student is not considered as a subject of educational services in Czech law [24].

\section{Poland}

The new Low regulating educational activities in higher education declares that "The University conducts training..." [25, Art.53.1]. This Law describes the rights of students. However, they are not associated with the consumption of educational services. Based on this, Polish student is not considered as a subject of educational services.

\section{Serbia}

The Law on Higher Education [26] is dominated by the curriculum that students need to apply and develop professional knowledge and skills. A plus for Serbian students is that they imply the participation of students in management and decision-making, especially in connection with issues that matter for the quality of education.

In the Law, from the point of view of the authors, excessive attention is paid to the process of accreditation and control. This may indicate a weak influence on the educational services market by consumers. So, they are not considered as the subjects of educational services.

Russia

In the Law "On Education in the Russian Federation" student cannot constitute a "task" for the "provider" and cannot influence the quality of the paid educational services provided [27, 28]. Therefore, it cannot be considered a subject of educational activity.

\section{Ukraine}

You can see three sources of educational services [29]: the state, the educational program and the agreement. In addition, the definition of "educational services" is associated with the expected learning outcomes. That is, the interests of the applicant are taken into account. Therefore, the applicant can be considered the subject of educational services.

\subsection{The Common Picture Related to the Subjects of Educational Services in the Selected East European Countries}

What did the literature review show? It showed three facts:

1. There is an international document that regulates the relationship between the provider and the consumer of educational services.

2. According to the Laws in a number of East European countries, students are considered subjects of educational services. In other countries, this is not the case.

3. We got an overall picture. It is not a strictly scientific evidence. The expansion of the number of countries will not give us a new result.

Our goal is in analyzing the relationship between the provider and the consumer of educational services in East Europe. Therefore, the author started to processing the data obtained in the second part of the literature review.

\section{Results}

\subsection{Processing and Grouping of Results}

Let's transform the data from the second part of the 
literature review into a tabular form. Table 1 summarizes the results of subsection 2.2. Let's focusing on one aspect: are students of East European universities subjects of educational services or not?

Table 1. Legal relations between the subjects of educational services in some East European countries

\begin{tabular}{|c|c|c|}
\hline No & Country & $\begin{array}{c}\text { Students are subjects of educational } \\
\text { services }\end{array}$ \\
\hline 1 & 2 & 3 \\
\hline 1 & Azerbaijan & No \\
\hline 2 & Belarus & Yes \\
\hline 3 & Croatia & No / Yes* \\
\hline 4 & Czech & No \\
\hline 5 & Pepublic & No \\
\hline 6 & Serbia & No \\
\hline 7 & Russia & No \\
\hline 8 & Ukraine & Yes \\
\hline
\end{tabular}

* - Students are not subjects of educational services.

The data in Table 1 does not provide a clear answer to the question: are students of East European universities subjects of educational services or not? Table 1 shows that, in a number of East European countries, students are subjects of educational services. In other countries, they are not. Verification of statistical hypotheses can provide a scientifically based answer.

Table 2. Statistical data for verification of statistical hypotheses

\begin{tabular}{|c|c|c|}
\hline No & Country & $\begin{array}{c}\text { Students are subjects of educational } \\
\text { services }\end{array}$ \\
\hline 1 & 2 & 3 \\
\hline 1 & Azerbaijan & 0 \\
\hline 2 & Belarus & 1 \\
\hline 3 & Croatia & $0.5^{*}$ \\
\hline 4 & Czech Republic & 0 \\
\hline 5 & Poland & 0 \\
\hline 6 & Serbia & 0 \\
\hline 7 & Russia & 1 \\
\hline 8 & Ukraine & 8 \\
\hline 9 & Sample size, $\mathrm{n}$ & 0.31 \\
\hline 10 & $\begin{array}{c}\text { Average of sample } \\
\dot{X}_{\mathrm{i}}\end{array}$ & 0.43 \\
\hline 11 & $\begin{array}{c}\text { Statistical deviation } \\
\delta_{\mathrm{i}}\end{array}$ \\
\hline
\end{tabular}

* - Students are not subjects of educational services. Adults are subjects of educational services.

Table 2 contains the modified values of column 3 (Table 1). It is assumed, that the case, when students are subject of educational services, receives the value 1.0 (one). The case, when students are not subject of educational services, receives the value 0.0 (zero). If you explain this simply, you replaced the answer "Yes" to the number " 1 " in the third column. And you replaced the answer "No" to the number "0" in the third column. On this basis, you can calculate the average of sample $\dot{X}_{\mathrm{i}}$ and statistical deviation $\delta_{\mathrm{i}}$.

Table 2 allows us to start verification of statistical hypotheses. Now you can check are students of East European universities subjects of educational services or not? Previously, we suggested that students of East European universities are subjects of educational services. We suggested this because there is a standard ISO 9001:2015 [18]. And it must be executed.

The author will formulate Research and Alternative hypotheses below. After that, verification of statistical hypotheses will be performed.

\subsection{Verification of Statistical Hypotheses}

Further statistical calculations apply only to students of East European universities.

Because, the case, when students are subject of educational services, receives the value 1.0 (one), the author writes the Research Hypothesis in the form: $\mu_{0}=$ 1.0. It means that students of East European universities are subjects of educational services.

The Research Hypothesis: students are subject of educational services. In other words, the percentage of students who are subject of educational services equals to $100,0 \%$, if random deviations will not to take into account.

The Alternative Hypothesis is written: $\mu_{0} \neq 1,0$.

The Alternative Hypothesis: students are not subject of educational services. In other words, the percentage of students who are subject of educational services does not equal to $100 \%$, if random deviations will not to take into account.

The method of testing of the hypothesis about the average of General population is to calculate t-statistics [16]:

$$
\mathrm{t}_{\text {stat }}=\left(\dot{\mathrm{X}}-\mu_{0}\right) / \dot{\mathrm{S}}_{\dot{\mathrm{X}}},
$$

- $\dot{X}$ - Average of sample,

- $\mu_{0}$ - specified number,

- $\dot{\mathrm{S}}_{\mathrm{X}}$ - Average error.

Table 3 shows the results of verification of statistical hypotheses.

If in Table 3, t-statistics in absolute $\left|t_{\text {stat }}\right|$ is larger the ttabl, we reject the Research Hypothesis and accept the Alternative Hypothesis: students are not subject of educational services. 
Table 3. The verification of statistical hypotheses: students are subject of educational services. The checking level is $1.0 \%$

\begin{tabular}{|c|c|c|}
\hline No & Indicator & Result \\
\hline 1 & Sample size, $\mathrm{n}$ & 8 \\
\hline 2 & Average of sample, $\dot{\mathrm{X}}$ & 0.31 \\
\hline 3 & Standard deviation for sample, $\delta_{\mathrm{x}}$ & 0.43 \\
\hline 4 & Average error, $\dot{\mathrm{S}}_{\dot{\mathrm{X}}}=\delta_{\mathrm{x}} / \sqrt{\mathrm{n}}$ & 0.150 \\
\hline 5 & Value $\left|\mathrm{t}_{\text {stat }}\right|$ for $\mu_{0}=1,0,\left(\dot{\mathrm{X}}-\mu_{0}\right) / \dot{\mathrm{S}}_{\dot{\mathrm{X}}}$ & 4.600 \\
\hline 6 & $\begin{array}{c}\text { Value } \mathrm{t}_{\text {tabl }} \text { for significance level } 99,0, \%,[16, \\
\text { p. 42] }\end{array}$ & 3.499 \\
\hline 7 & Result, $\left|\mathrm{t}_{\mathrm{stat}}\right|>\mathrm{t}_{\mathrm{tabl}}$ & Yes \\
\hline 8 & The accepted hypothesis & Alternative \\
\hline
\end{tabular}

The observed difference between the statistical average $\dot{X}$ and a specified value of $\mu_{0}=1.0$ cannot be explain by coincidence only. Since the difference exceeds a simple coincidence, students are not subject of educational services, if random deviations will not to take into account.

It was statistically proved that students of East European universities are not subject of educational services. The result is highly statistically significant (0.01).

This proven scientific fact shows that East European countries do not follow with ISO 9001:2015 requirements [18]. Thus, this proven fact requires combining the efforts of scientists of different specialties, such as law, economics and pedagogy. A cooperative work of scientists should provide evidence-based recommendations to the governments of Eastern Europe. These recommendations should be aimed at correcting national Legislation. The governments of Eastern European countries should adopt Laws that treat students as subjects of educational services. Also, the governments should Fund research of the educational services market in Eastern Europe.

The authorities of East European universities can correct the training programs for university teachers. These programs should teach university teachers to see students as partners in the educational process or consumers of educational services.

As a result, students of East European universities will be subjects of educational services.

\section{Discussion}

It was studied the legal relations between the subjects of educational services in several countries of Eastern Europe. In fact, students are the subjects of educational services in some countries. At the same time, students are not the subjects of educational services in other countries. In our research it was statistically proved that students of East European universities are not subject of educational services. The Alternative hypothesis was accepted. This result is stronger compared to the case when the Research hypothesis is accepted. Considering Laws in all East European countries does not make sense. The increase in the number of countries will not make it possible to obtain a qualitatively new knowledge in this matter.

Let's turn to international standards as external regulators of attitudes towards educational services in the countries of Eastern Europe.

In most of the examples discussed above, national laws do not comply with this principle of ISO 9001:2015 (customer orientation). In most of the examples discussed above, students are not considered as consumers of educational services. This suggests that the conditions for the provision and receipt of educational services in the countries of Eastern Europe must be changed. Namely, national laws, primarily, should become consumer-oriented educational services.

Can you trust the results of the study?

The result is highly statistically significant $(0.01)$. That is why, the results suggest that, the decision will be correct in approximately $99.0 \%$ of the cases and incorrect in $1.0 \%$ of cases only. In this sense, you have the decision-making process with accurate, controlled probability.

\section{Conclusions}

The goal of the study is achieved: the author has verified the hypothesis. The results have a very important scientific and practical significance:

1. The legal relations between the subjects of educational services in some countries of Eastern Europe have been deeply studied. It is statistically proven that students of East European universities are not subjects of educational services. The result is highly statistically significant (0.01).

This proven scientific fact requires combining the efforts of scientists of different specialties, such as law, economics and pedagogy. The cooperation of scientists should provide evidence-based recommendations. These recommendations should be aimed at correcting national Legislation.

2. The authorities of East European universities can correct the training programs for university teachers. These programs should teach university teachers to see students as partners in the educational process (consumers of educational services).

3. The governments of East European countries should adopt Laws that treat students as subjects of educational services. Also, the governments should fund research of the educational services market in Eastern Europe.

In general, the legal conditions for the provision and receipt of educational services in East European universities, much more primarily, should become consumer-oriented. As a result, students of East European 
universities will be subjects of educational services.

4. The aim of the next study is to analyze legal relations between the subjects of educational services in West European countries.

\section{Acknowledgements}

The author would like to thank reviewers for their insightful comments on an earlier draft of this manuscript.

\section{REFERENCES}

[1] Y. M. Dora, K. Kaniawati, N. Nurani. Service Quality, Student Satisfaction and Decision in Remaining Active to Study - Study at Private Universities in West Java. Universal Journal of Educational Research, 7(5A), 18-23, 2019.

[2] J. A. Douglas, A. Douglas, R. J. McClelland, et al. Understanding student satisfaction and dissatisfaction: an interpretive study in the UK higher education context, Studies in Higher Education, 40:2, 329-349, 2015.

[3] R. Maxwell-Stuart, B. Taheri, A. S. Paterson, et al. Working together to increase student satisfaction: exploring the effects of mode of study and fee status, Studies in Higher Education, 43:8, 1392-1404, 2018.

[4] L. Bunce, A. Baird, S. E. Jones. The student-as-consumer approach in higher education and its effects on academic performance. Studies in Higher Education, 42:11, 1958-1978, 2017.

[5] S. I. Belentsov, V. A. Gribanova, O. U. Brasnik, et al. Management of development of creative civil activity of student's youth. European Journal of Contemporary Education, 7(2): 257-264, 2018.

[6] R. Baker, B. Evans, Q. Li, et al. Does Inducing Students to Schedule Lecture Watching in Online Classes Improve Their Academic Performance? An Experimental Analysis of a Time Management Intervention. Research in Higher Education. First Online: 28 July, 1-32, 2018.

[7] Ja. Alieva, et al. Management of higher education in Azerbaijan: What lectures do students prefer? Konferencja Miedzynarodowa Naukowo-Praktyczna "Science, Research, Development, \#5: Economy. Management", Barcelona, 66-67, 2018.

[8] S. Goić, et al. Educational services management in Croatia: What lectures do students prefer? Konferencja Miedzynarodowa Naukowo-Praktyczna "Science, Research, Development \#6: Economy. Management. State and Law", Baku, 69-70, 2018.

[9] S. Isaeva, et al. Statistical Research of Preferences of Students of the Moscow Pedagogical State University in Lectures, Zeszyty Naukowe Wydziału Nauk Ekonomicznych, Vol. 1, No.22, 355-365, 2018.

[10] O. Lapitskaya, et al. Higher education as a business: should
Belarusian Universities change the way of teaching at lectures? Journal of Economy and Business, Vol. 5, No.2, 5-10, 2018.

[11] V. Okulich-Kazarin, M. Zhurba, O. Pagava, et al. Lecture method preferences, auditory or visual, of Ukrainian consumers of educational services: a statistical analysis, International Journal of Education and Practice, Vol. 7, No.2, 54-65, 2019.

[12] V. Okulich-Kazarin, M. Zhurba, Y. Bokhonkova, et al. Three Scientific Facts about Ukrainian and Polish Law-students: Verification of statistical hypotheses about their Preferences of Learning at Lectures. European Journal of Contemporary Education, 8(3), 562-573, 2019.

[13] D. Škunca, Z. Čekerevac, O. Golubyonkova, et al. Experience in assessing the priorities of consumers of educational services in universities in Serbia and Ukraine, V International Scientific Conference "Економічні та соціальні аспекти розвитку України на початку XXI століття", Odesa, 207-210, 2018.

[14] W. Okulicz-Kozaryn. Study of definition of "educational services" in economic science. Journal of Economy and Business, vol.1, 180-187, 2019

[15] J. M. Balkin. "Understanding Legal Understanding: The Legal Subject and the Problem of Legal Coherence". Faculty Scholarship Series. 273, 1993.

[16] Textbook BUS_9641_5M. Business_Statistics. Textbook for the Program "Masters of Business Administration". NY: Kingston University, 2010.

[17] O. Levchuk. Concept of educational services [In Russian]: Online available from https://nsportal.ru/vuz/pedagogiches kie-nauki/library/2012/12/01/ponyatie-obrazovatelnoy-uslu gi(11 December 2016).

[18] ISO 9001: 2015. Quality management systems. Requirements.

[19] Law of the Republic of Azerbaijan. On Education. 2009.

[20] Code of the Republic of Belarus "On Education", № 243-3, 2011.

[21] Zakon o visokom obrazovanju (Prečišćeni tekst) objavljen je u «Službenim novinama Kantona Sarajevo» broj 22/10.

[22] Zakon o znanstvenoj djelatnosti i visokom obrazovanju: Online available from https://www.zakon.hr/z/320/ (20 April 2018).

[23] Zakon o obrazovanju odraslih: Online available from https://www.zakon.hr/z/384/Zakon-o-obrazovanju-odraslih (20 April 2018).

[24] Law № 111/1998 Coll. Higher Education Act. Current version: Online available from https://www.zakonyprolidi. cz/cs/1998-111/zneni-20180101 (01 January 2018).

[25] Ustawa z dnia 20 lipca 2018 r. Prawo o szkolnictwie wyższym i nauce, 2018.

[26] Zakon o visokom obrazovanju. Official Gazette of the Republic of Serbia, № 88, 2017.

[27] N. Ageshkina. The concept and main types of educational services [In Russian]: Online available from http://www.fi 
nexg.ru/ponyatie-i-osnovnye-vidy-obrazovatelnyx-uslug (17 October 2016).

[28] Federal Law No. 273-FZ (as amended on 27.06.2018) "On education in the Russian Federation", 2012.

[29] Law of Ukraine No. 2145-VIII "On Education", 2017. 